\title{
Kontribusi Dukungan Keluarga dan Sikap dalam Penguatan Mekanisme Koping Pasien HIV/AIDS di Poli VCT RSUD Raden Mattaher Jambi
}

\author{
Debbie Nomiko ${ }^{1 *}$, Yellyanda ${ }^{2}$, Bettywaty Eliezer $^{3}$, Ayu Maryastuty ${ }^{4}$ \\ 1,2,3 Jurusan Keperawatan Poltekkes Kemenkes Jambi \\ Jln. DR Tazar No 05 Buluran Telanai Pura Jambi \\ ${ }^{4}$ RSUD Raden Mattaher Jambi \\ Jln. Letjen Suprapto No.31 Telanai Pura Jambi \\ *Correspondence email: nomikodebbiejambi@gmail.com
}

\begin{abstract}
Abstrak. Acquired Immunodeficiency Syndrome (AIDS) adalah sekumpulan penyakit yang timbul karena turunnya kekebalan tubuh yang didapat. Penelitian ini bersifat deskriptif analitik dengan desain Cross Sectional yang bertujuan mengetahui gambaran hubungan dukungan keluarga dan sikap dengan mekanisme koping pasien HIV/AIDS di Poli VCT RSUD Raden Mattaher Jambi Tahun 2018. Penelitian ini telah dilaksanakan pada bulan April 2018. Populasi pada penelitian ini adalah seluruh pasien HIV/AIDS yang berkunjung di Poli VCT yang berjumlah 74 orang. Sampel pada penelitian ini diambil sebanyak 34 orang menggunakan teknik Purposive sampling. Teknik pengumpulan data yang akan dilakukan adalah menggunakan kuesioner dan analisis data yang digunakan yaitu analisis univariat dan bivariat uji chi-square. Hasil penelitian menunjukan bahwa mayoritas responden memiliki dukungan keluarga baik sebanyak 20 orang $(58,8 \%)$, sikap positif sebanyak 23 orang $67,6 \%)$, dan mekanisme koping baik sebanyak 18 orang $(52,9 \%)$, ada hubungan dukungan keluarga dengan mekanisme koping pasien HIV/AIDS dengan p-value 0,001, dan ada hubungan sikap dengan mekanisme koping pasien HIV/AIDS dengan p-value 0,015. Diharapkan hasil penelitian ini menjadi bahan kontribusi bagi pihak manajemen keperawatan RSUD Raden Mattaher Jambi dalam rangka meningkatkan pelayanan keperawatan bagi pasien HIV AIDS di Poli VCT khususnya yang terkait dengan penanganan masalah psikologis (mekanisme koping) pasien beserta aspek-aspek yang terkait di dalamnya.
\end{abstract}

Kata Kunci: Dukungan keluarga; Sikap; Mekanisme Koping; HIV/AIDS

Abstract. Acquired Immunodeficiency Syndrome (AIDS) is a group of diseases that arise due to a decrease in acquired immunity. This research is descriptive-analytic with a cross-sectional design that aims to describe the relationship between family support and attitudes with coping mechanisms for HIV/AIDS patients at the VCT Poly Hospital Raden Mattaher Jambi in 2018. This study was carried out in April 2019. The population in this study was all 74 HIV/AIDS patients who visited the VCT Polyclinic. The sample in this study was taken as many as 34 people using the purposive sampling technique. The data collection technique that will be carried out is using a questionnaire and the data analysis used in univariate analysis and bivariate chi-square test. The results showed that the majority of respondents had good family support as many as 20 (58.8\%), positive attitudes as many as 23 (67.6\%) and good coping mechanisms as many as 18 (52.9\%), there is a relationship between family support and coping mechanisms of HIV/AIDS patients with p-value 0.001, and there is a relationship between attitudes and coping mechanisms of HIV/AIDS patients with p-value 0.015. It is hoped that the results of this study will contribute to the nursing management of Raden Mattaher Jambi Hospital to improve nursing services for HIV AIDS patients at the VCT Polyclinic, especially those related to handling psychological problems (coping mechanisms) of patients and the related aspects in it.

Keywords: Family Support; Attitudes; Coping Mechanisms; HIV/AIDS

\section{PENDAHULUAN}

Acquired Immunodeficiency Syndrome atau Acquired Immune Deficiency Syndrome (AIDS) adalah sekumpulan penyakit yang timbul karena turunnya kekebalan tubuh yang didapat. AIDS disebabkan oleh adanya virus HIV yang hidup di dalam 4 cairan tubuh manusia yaitu cairan darah, cairan sperma, cairan vagina, dan air susu ibu (Brunner, 2016). Situasi penyakit HIV dan AIDS terus mengalami peningkatan tiap tahunnya,berdasarkan data WHO prevalensi penyakit AIDS tahun 2020 sebesar 37,3 juta orang, dengan angka kematian sebesar 680.000 orang meninggal karena HIV AIDS.(WHO Update, 2020). Sedangkan prevalensi penyakit AIDS di Indonesia untuk triwulan kedua April-Juni 2020 sebanyak 7.993 orang. Di provinsi Jambi dilaporkan jumlah penderita AIDS pada tahun 2019 sebanyak 131 orang dengan penambahan kasus baru sebanyak 11 orang. (KEMENKES RI, 2020) Ketika seseorang terdiagnosa HIV AIDS, akan mengalami kondisi kecemasan, rasa bersalah, dan depresi, akibat lebih lanjut bisa berakibat bunuh diri. (Aruben, 2012). Berbagai dampak dapat ditimbulkan antara lain dampak psikologis, social dan ekonomi. Dampak psikologis berupa stress (Irianto, 2015), bersalah, marah dan tidak berdaya, mengucilkan diri sendiri, membuka status secara terbatas, mencari orang lain yang terkena HIV positif (Nursalam, 2005) dalam Pardita (2014), sedangkan dampak sosial yang dapat ditimbulkan pada pasien penderita HIV/AIDS pada pada pola budaya, yang menyebabkan $90 \%$ penderitanya tidak terakses oleh pelayanan kesehatan. (Andersen , 2002) dalam Pardita (2014), dan dampak 
Debbie Nomiko, Yellyanda, Bettywaty Eliezer dan Ayu Maryastuty, Kontribusi Dukungan Keluarga dan Sikap dalam Penguatan Mekanisme Koping Pasien HIV/AIDS di Poli VCT RSUD Raden Mattaher Jambi

ekonomi yang ditimbulkan berupa obat belum ditemukan dan kemungkinan kesulitan memperoleh dana (Irianto, 2015).

Konflik yang kompleks pada pasien ODHA (Orang Dengan HIV AIDS) menyebabkan mereka memilih mengasingkan diri dari lingkungan social, yang dapat memperburuk kondisi mereka. Konflik yang dihadapi antara lain konflik dengan diri sendiri, konflik dengan keluarga, masalah kesehatan, serta kebutuhan akan informasi penyakit yang diderita, serta diskriminasi dari masyarakat (Kusmini, 2010)

Semua dampak negatif yang dirasakan oleh penderita ODHA perlu diatasi dengan cara melakukan mekanisme koping kearah adaptif. (Sandu, Yuli, \& Eva, 2016). Sikap individu berbeda mekanisme koping yang dipakainya dalam menghadapi masalah yang dihadapi Penggunaan strategi koping yang adaptif bertujuan mengurangi dampak negatif akibat tekanan yang ditimbulkan oleh penyakit. (Salami, Muvira, \& Yualita, 2021). Penggunaan strategi koping berfokus pada penyelesaian masalah berdampak positif terhadap pasien HIV AIDS.(Priharwanti \& Raharjo, 2018).

Mekanisme koping merupakan suatu usaha individu untuk melakukan atau mengatasi perubahan yang dihadapi atau beban yang diterima meskipun dalam situasi mengancam. Banyak faktor yang mempengaruhi mekanisme koping diantaranya kesehatan fisik, pandangan positif, ketrampilan memecahkan masalah, ketrampilan sosial dan dukungan sosial. Dukungan keluarga merupakan faktor yang paling penting dalam upaya meningkatkan adaptasi pasien terhadap penyakit yang dideritanya (Shor, Roelfs, \& Yogev, 2013), dan efek negatif stress berat akibat penyakit dapat dihindari dengan adanya dukungan social. (Nursalam, 2013).

Berdasarkan hasil survei awal yang dilakukan terhadap 7 orang pasien HIV/AIDS yang berkunjung di Ruang VCT yaitu terdapat 6 dari 7 responden mengatakan terkena penyakit HIV menjadi sulit untuk berkonsentrasi dalam memecahkan masalah, mencari informasi penyakit HIV, tidak yakin bahwa penyakit HIV dapat diobati, kurangnya minat untuk mengerjakan aktivitas dan sulit untuk bergaul dikalangan masyarakat, merasa bersalah dan dukungan keluarga sebagian memiliki tanggapan negatif karena sulit menerima anggota keluarga yang terkena HIV/AIDS karena ini merupakan aib keluarga dan 3 orang dari 7 orang mengatakan tidak didukung keluarga selama menderita penyakit ini seperti sulit menerima.

Rumah Sakit Raden Mattaher Jambi memiliki ruang VCT (Voluntary Counseling and Testing HIV/AIDS) sebagai sarana pelayanan kesehatan khusus pasien HIV AIDS, berdasarkan data selama 3 tahun terakhir tercatat jumlah pasien HIV AIDS yang berkunjung yaitu tahun 2018 sebanyak 74 orang, 2019 sebanyak 71 orang dan tahun 2020 sebanyak 74 orang (Rekam Medis, RSUD Raden Mattaher Jambi, 2020)

Berdasarkan uraian latar belakang diatas, maka penulis tertarik untuk menulis artikel tentang hubungan dukungan keluarga dan sikap dengan mekanisme koping pasien HIV/AIDS di Poli VCT RSUD Raden Mattaher Jambi.

\section{METODE}

Jenis penelitian ini adalah jenis penelitian kuantitatif dengan menggunakan desain crossectional yang bertujuan menggambarkan hubungan antar variabel independen (dukungan keluarga dan sikap) dengan variabel dependen (mekanisme koping) dalam waktu bersamaan..

Penelitian dilaksanakan di RSUD Raden Mattaher. Populasi dalam penelitian ini adalah seluruh pasien penderita HIV yang berkunjung ke Poli VCT sebanyak 74 pasien pada tahun 2018. Jumlah sampel dalam penelitian ini sebanyak 34 orang yang diambil dengan kriteria inklusi yaitu penderita HIV AIDS yang berkunjung ke poli VCT periode April 2018 dan bersedia menjadi responden.Tekhnik pengambilan sampel secara purposive sampling.

Pengumpulan data menggunakan kuisioner berisi pertanyaan tentang karakteristik responden, dukungan keluarga, sikap keluarga dan mekanisme koping pasien HIV AIDS. Semua item pertanyaan menggunakan skala Likert empat poin

\section{HASIL DAN PEMBAHASAN Karakteristik Demografi Responden}

Tabel 1. Distribusi Responden menurut Karakteristik Demografi di RSUD Raden Mattaher Jambi

\begin{tabular}{clcc}
\hline No & Umur & N & \% \\
\hline 1 & 20-35 Tahun & 18 & 52,9 \\
2 & > 35 Tahun & 16 & 47,1 \\
& Jumlah & 34 & 100 \\
No & Jenis Kelamin & $\mathbf{N}$ & \% \\
1 & Laki-Laki & 23 & 67,6 \\
2 & Perempuan & 11 & 32,4 \\
& Jumlah & 34 & 100 \\
No & Pekerjaan & $\mathbf{N}$ & \% \\
1 & Petani & 3 & 8,8 \\
2 & Pedagang & 4 & 11,8 \\
3 & PNS & 5 & 14,7 \\
4 & Wiraswasta & 15 & 44,1 \\
5 & Dan Lain-Lain & 7 & 20,6 \\
& Jumlah & 34 & 100 \\
No & Perkawinan & $\mathbf{n}$ & \% \\
1 & Menikah & 20 & 58,8 \\
2 & Belum Menikah & 14 & 41,2 \\
& Jumlah & 34 & 100 \\
\hline
\end{tabular}

Tabel 1. Menunjukkan bahwa karakteristik demografi responden mayoritas proporsinya beradai di rentang usia 20-3 tahun (52\%), laki-laki $(67,6 \%)$, wiraswasta $(44,1 \%)$ dan menikah $(58,8 \%)$.

Hal ini tidak jauh berbeda dengan data dari (KEMENKES RI, 2020) bahwa usia kelompok umur 25- 
Debbie Nomiko, Yellyanda, Bettywaty Eliezer dan Ayu Maryastuty, Kontribusi Dukungan Keluarga dan Sikap dalam Penguatan Mekanisme Koping Pasien HIV/AIDS di Poli VCT RSUD Raden Mattaher Jambi

49 tahun (usia produktif) merupakan proporsi umur dengan jumlah kasus HIV terbanyak setiap tahunnya, dan seb $>60 \%$ berjenis kelamin laki-laki. dan sejalan dengan penelitian (Sandu et al., 2016) bahwa distribusi umur terbanyak pada rentang usia 25-35 tahun (67\%) dan berjenis kelamin laki-laki (60\%).

\section{Analisis Univariat \\ Dukungan Keluarga, Sikap dan Mekanisme Koping Responden}

Tabel 2. Distribusi Frekuensi berdasarkan Variabel Dukungan Keluarga, Sikap dan Mekanisme Koping Responden di RSUD Raden Mattaher Jambi

\begin{tabular}{clcc}
\hline No & \multicolumn{1}{c}{ Variabel } & Frekuensi (n) & Persentase (\%) \\
\hline 1 & Dukungan & & \\
& Keluarga & & \\
& Optimal & 20 & 58,8 \\
& Minimal & 14 & 41,2 \\
& Jumlah & 34 & 100 \\
2 & Sikap & & \\
& Positif & 23 & 67,6
\end{tabular}

Negatif

Jumlah

3 Mekanisme

Koping

Adaptif

Maladaptif

Jumlah

11

34

32,4

100

Tabel 2 menunjukkan bahwa sebagian responden mendapatkan dukungan keluarga yang optimal $(58,8 \%)$. Hasil penelitian juga menunjukkan bahwa sebagian besar proporsi responden berpandangan positif $(67,6 \%)$ dan mempunyai mekanisme koping yang adaptif $(52,9 \%)$. Hal ini sejalan dengan dengan hasil penelitian (Izzati \& Vahana, 2014) bahwa sebagian responden mendapatkan dukungan keluarga yang optimal $(52,5 \%)$ dan mempunyai mekanisme koping yang adaptif (55\%), dan ini berbeda hasilnya pada penelitian (Sandu et al., 2016) bahwa $60 \%$ responden mempunyai koping mal adaptif.

Tabel 3. Aspek Dominan Variabel Dukungan Keluarga, Sikap dan Mekanisme Koping Responden di RSUD Raden Mattaher Jambi

\begin{tabular}{|c|c|c|c|c|c|c|c|c|c|}
\hline \multirow[t]{2}{*}{ No } & \multirow[t]{2}{*}{ Pernyataan } & \multicolumn{2}{|c|}{ Selalu } & \multicolumn{2}{|c|}{ Sering } & \multicolumn{2}{|c|}{ Jarang } & \multicolumn{2}{|c|}{$\begin{array}{l}\text { Tidak } \\
\text { Pernah }\end{array}$} \\
\hline & & $\mathrm{F}$ & $\%$ & $\mathrm{f}$ & $\%$ & $\mathrm{~F}$ & $\%$ & $\mathrm{f}$ & $\%$ \\
\hline & \multicolumn{9}{|l|}{ Dukungan Keluarga } \\
\hline 1 & Pendampingan saat berobat ke pusat pelayanan kesehatan & 21 & 61,8 & 5 & 14,7 & 5 & 14,7 & 3 & 8,8 \\
\hline 2 & Pemberian semangat dan inspirasi untuk menghadapi kondisi yang terjadi & 18 & 52,9 & 12 & 35,3 & 1 & 2,9 & 3 & 8,8 \\
\hline 3 & Pengontrolan aktivitas di masa pengobatan & 17 & 50 & 13 & 38,2 & 3 & 8,8 & 1 & 2,9 \\
\hline 4 & Menyediakan waktu dalam pendampingan berobat & 13 & 38,2 & 9 & 26,5 & 9 & 26,5 & 3 & 8,8 \\
\hline \multirow[t]{2}{*}{5} & Pemberian motivasi dalam beraktivitas & 8 & 23,5 & 20 & 58,8 & 6 & 17,6 & 0 & 0 \\
\hline & \multicolumn{9}{|l|}{ Sikap } \\
\hline 1 & Berusaha bersikap tenang pada saat down & 27 & 79,4 & 7 & 20,6 & 0 & 0 & 0 & 0 \\
\hline 2 & HIV dapat menyerang siapa saja tanpa melihat status kehidupan sosial seseorang & 22 & 64,7 & 12 & 35,3 & 0 & 0 & 0 & 0 \\
\hline 3 & Menderita penyakit HIV karena biasanya diakibatkan prilaku seksual yang tidak aman & 20 & 58,8 & 14 & 41,2 & 0 & 0 & 0 & 0 \\
\hline 4 & Pencarian informasi HIV merupakan hal yang sangat krusial dalam pengobatan & 19 & 55,9 & 15 & 44,1 & 0 & 0 & 0 & 0 \\
\hline \multirow[t]{2}{*}{5} & Keteraturan minum obat dapat membantu meningkatkan daya tahan tubuh & 18 & 52,9 & 16 & 47,1 & 0 & 0 & 0 & 0 \\
\hline & \multicolumn{9}{|l|}{ Mekanisme Koping } \\
\hline 1 & Mengurung diri dan tidak mau bersosialisasi & 23 & 67,6 & 11 & 32,4 & 0 & 0 & 0 & 0 \\
\hline 2 & Melakukan pendekatan spiritual kepada Tuhan & 20 & 58,8 & 14 & 41,2 & 0 & 0 & 0 & 0 \\
\hline 3 & Menangis, dan meratapi diri & 17 & 50 & 17 & 50 & 0 & 0 & 0 & 0 \\
\hline 4 & Mencari informasi terkait penyakit HIV & 16 & 47,1 & 18 & 52,9 & 0 & 0 & 0 & 0 \\
\hline 5 & Relaksasi dengan music dan refresing dengan kegiatan menyenangkan & 15 & 44,1 & 19 & 55,9 & 0 & 0 & 0 & 0 \\
\hline
\end{tabular}

Tabel 3 menjelaskan bahwa dari variabel dukungan keluarga maka aspek pendampingan keluarga dalam berobat ke pelayanan kesehatan merupakan mayoritas aspek dengan katagori paling dominan dikerjakan $(61,8 \%)$, sejalan dengan hasil penelitian (Wardoyo, Budyono, \& Asmara, 2018) dimana pemberian nasehat yang diterima pasien merupakan aspek yang paling dominan dalam dukunga nkeluarga yang diharapkan, selanjutnya aspek pandangan tentang bersikap tenang pada saat ada masalah pada individu merupakan mayoritas aspek dengan katagori paling dominan dipersepsikan $(79,4 \%)$, dan responden dominan melakukan mekanisme koping maladaptif yaitu tidak bersosialisasi dengan orang lain $(67,6 \%)$

\section{Analisis Bivariat}

Tabel 4. Hubungan Dukungan Keluarga dengan Mekanisme Koping pada pasien HIV/AIDS di Poli VCT RSUD Raden Mattaher Jambi

\begin{tabular}{|c|c|c|c|c|c|c|c|}
\hline \multirow{3}{*}{$\begin{array}{l}\text { Dukungan } \\
\text { Keluarga }\end{array}$} & \multicolumn{4}{|c|}{ Mekanisme Koping } & \multirow{2}{*}{\multicolumn{2}{|c|}{ Jumlah }} & \multirow{3}{*}{ P-Value } \\
\hline & \multicolumn{2}{|c|}{ Adaptif } & \multicolumn{2}{|c|}{ Maladaptif } & & & \\
\hline & f & $\%$ & $\mathrm{~F}$ & $\%$ & f & $\%$ & \\
\hline Optimal & 16 & 80 & 4 & 20 & 20 & 100 & \\
\hline Minimal & 2 & 14,3 & 12 & 85,7 & 14 & 100 & 0,001 \\
\hline Jumlah & 18 & 52,9 & 16 & 47,1 & 34 & 100 & \\
\hline
\end{tabular}

Dari 34 responden (100\%) mayoritas responden memiliki dukungan keluarga optimal sebanyak 20 orang yang memiliki mekanisme koping adaptif sebanyak 
Debbie Nomiko, Yellyanda, Bettywaty Eliezer dan Ayu Maryastuty, Kontribusi Dukungan Keluarga dan Sikap dalam Penguatan Mekanisme Koping Pasien HIV/AIDS di Poli VCT RSUD Raden Mattaher Jambi

16(80\%). Hasil penelitian dengan menggunakan uji chisquare menunjukan bahwa ada hubungan dukungan keluarga dengan mekanisme koping pasien HIV/AIDS dengan p-value $(0,001)<0,05$ dengan $C I$ (Confidence interval) : $95 \%$ yang bermakna semakin baik dukungan keluarga yang diberikan kepada responden, maka semakin baik mekanisme koping yang dilakukan responden

Tabel 5. Hubungan Sikap dengan Mekanisme Koping pada pasien HIV/AIDS di Poli VCT RSUD Raden Mattaher Jambi

\begin{tabular}{lcccccccc}
\hline \multirow{3}{*}{ Sikap } & \multicolumn{9}{c}{ Mekanisme Koping } & \multirow{2}{*}{ Jumlah } & \multirow{2}{*}{ P-Value } \\
\cline { 2 - 5 } & \multicolumn{2}{c}{ Adaptif } & \multicolumn{3}{c}{ Maladaptif } & & & \\
\cline { 2 - 5 } & f & $\%$ & f & $\%$ & f & $\%$ & \\
\hline Positif & 16 & 69,6 & 7 & 30,4 & 23 & 100 & \\
Negatif & 2 & 18,2 & 9 & 81,8 & 11 & 100 & 0,015 \\
Jumlah & 18 & 52,9 & 16 & 47,1 & 34 & 100 & \\
\hline
\end{tabular}

Dari 34 (100\%) mayoritas responden memiliki sikap positif 23 orang, sikap responden positif yang memiliki mekanisme koping baik sebanyak 16(69,6\%) Hasil penelitian dengan menggunakan uji chi-square menunjukan bahwa ada hubungan sikap dengan mekanisme koping pasien HIV/AIDS dengan p-value $(0,015)<0,05$ dengan CI (Confidence interval) : $95 \%$ yang bermakna semakin positif sikap responden semakin baik mekanisme koping yang dilakukan responden

Menurut Notoatmodjo (2010) sikap merupakan kesiapan mental, yaitu proses yang berlangsung dalam diri seseorang, bersama denga pengalaman individual masing-masing, mengarahkan dan menentukan respons terhadap berbagai objek dan situasi. Jadi dapat disimpulkan bahwa sikap adalah suatu proses penilaian yang dilakukan seseorang terhadap suatu objek atau situasi yang disertai adanya perasaan tertentu dan memberikan dasar kepada orang tersebut untuk membuat respons atau berprilaku dalam cara yang tertentu yang dipilihnya.

Dukungan keluarga merupakan pemberian bantuan nyata atau tidak nyata baik berupa informasi, dukungan emosional, atau pun kehadiran yang berpengaruh positif terhadap penerimanya, karena si penerima menerima keuntungan secara emosional dan mendapatkan saran dan kesan yang tepat pada dirinya. (Smet, 2014). Dukungan keluarga dapat berfungsi sebagai strategi pencegahan untuk mengurangi stress, dengan cara keluarga memberikan semangat dan motivasi serta menghibur pasien HIV/AIDS. (Friedman, 2010)

Dukungan keluarga yang baik memberikan memberikan pengaruh terhadap peningkatan self esteem sedangkan dukungan keluarga yang buruk meningkatkan resiko depresi pada pasien HIV/AIDS. (Valeria, et al, 2016) Dukungan keluarga yang efektif dapat mengurangi efek-efek negative karena adanya asumsi negative pada diri seseorang (Izzati \& Vahana, 2014)
Semua bentuk dukungan sangat diperlukan bagi anggota keluarga terutama anggota keluarga yang sedang sakit. Penelitian (Wardoyo et al., 2018) mendapatkan bahwa bentuk dukungan keluarga berupa pemberian tempat tinggal setelah subjek terdiagnosa HIV merupakan aspek yang sangat diharapkan, ditambahkan oleh (Wouters, Masquillier, \& le Roux Booysen, 2016) bahwa dukungan pemberian pelayanan dan dukungan informasi merupakan fokus utama dalam menguatkan mekanisme koping pasien

Dari hasil penelitian Amiya, et all (2014) bahwa dukungan keluarga merupakan faktor yang sangat berkontribusi sekali dalam membangun kesehatan mental pasien HIV AIDS, dan berpengaruh dalam pencegahan depresi dan bunuh diri. Faktor yang berhubungan dengan sistem support keluarga terhadap pasien HIV yaitu tanda dan gejala hiv, sitgma internal HIV, tingkat pendidikan dan gender. Teori Friedman (2010) menyatakan banyak faktor yang mempengaruhi pemberian dukungan keluarga kepada pasien diantaranya ukuran keluarga, usia dan kelas social ekonomi keluarga

Elemen dukungan keluarga yang sangat berhubungan dengan kesehatan mental pasien HIV AIDS adalah elemen emosional yaitu penunjukkan rasa cinta dan kasih sayang oleh keluarga, kemampuan mengutarakan perasaan ke keluarga, rasa berperan penting penting dalam keluarga, dan rasa dilibatkan dalam pembuatan keputusan dan elemen lainnya adalah elemen instrumental yaitu kebutuhan dipenuhi sandang pangan oleh keluarga dan perasaan didudukung oleh keluarga ketika sakit. (Amiya et al., 2014).

Manusia merupakan sistem yang dapat menyesuaikan diri melalui proses control yaitu mekanisme koping yang dimanifestasikan dengan caracara penyesuaian diri. (Roy, 2009). Mekanisme koping merupakan strategi individu dalam menyesuaikan diri dengan perubahan serta berespon terhadap situasi yang mengancam.

Menurut Hawari (2016) mekanisme koping dibagi menjadi 2 yaitu adaptif yaitu mekanisme yang mendukung fungsi integrasi, pertumbuhan, belajar dan mencapai tujuan. Kategorinya adalah berbicara pada orang lain, memecahkan masalah secara efektif, teknik relaksasi latihan seimbang dan aktivitas konstruktif.dan maladaptif yaitu mekanisme yang menghambat fungsi integrasi, menurunkan otonomi dan cenderung menguasai lingkungan. Kategorinya adalah makan berlebihan/ tidak makan, bekerja berlebihan dan melakukan pengelakan terhadap solusi..Koping yang adaptif berperan penting dalam mencegah gangguan penyakit baik berupa fisik, psikis, dan social (Nursalam, 2013). Serta usaha individu mengurangi beban yang diterima tubuh dan menghasilkan sifat non spesifik berupa stress (Hawari, 2016). Mekanisme koping yang mal adaptif berawal dari perasaan yang tidak berguna lagi akibat dari penolakan keluarga dan stigma masyarakat (Sandu et al., 2016) 
Debbie Nomiko, Yellyanda, Bettywaty Eliezer dan Ayu Maryastuty, Kontribusi Dukungan Keluarga dan Sikap dalam Penguatan Mekanisme Koping Pasien HIV/AIDS di Poli VCT RSUD Raden Mattaher Jambi

Hae- Chung Y (2008) mengatakan bila strategi koping digunakan sesuai maka dapat mempengaruhi pola pikir seseorang dan akhirnya dapat mengurangi stressor yang dirasakan, sehingga dapat memilih strategi tindakan yang positif dalam mengurangi masalah.

Untuk itu sangat diharapkan sekali peran perawat sebagai counselor dalam mengarahkan memotivasi pasien HIV AIDS dalam mendayagunakan mekanisme koping mereka dalam mengatasi permasalahan yang dihadapi

\section{SIMPULAN}

Persepsi sikap yang postif dan dukungan keluarga yang positif sangat berkontribusi dalam penggunaan mekanisme koping positif pasien HIV AIDS dalam menghadapi penyakitnya terutama aspek pendampingan pasien dalam berobat dan pemberian semangat dan inspirasi dalam menghadapi kondisi yang terjadi.

\section{DAFTAR PUSTAKA}

Amiya, R. M., Poudel, K. C., Poudel-Tandukar, K., Pandey, B. D., \& Jimba, M. (2014). Perceived family support, depression, and suicidal ideation among people living with HIV/AIDS: A crosssectional study in the Kathmandu Valley, Nepal. PLOS ONE, 9(3). https://doi.org/10.1371/journal.pone.0090959

Aruben, R. (2012). Proses Sitgmasi Penderita HIV/AIDS. Afiyah Fak Kesehatan Masyarakat UNDIP, I(1).

Brunner, S. (2016). Keperawatan Medikal Bedah. Jakarta: EGC.

Friedman. (2010). Keperawatan Keluarga , Teori dan Praktek (3rd ed.). Jakarta: EGC.

Hae-chung, Y. (2008). Stress and Quality of Life in Breast Cancer Recurrence: Mediation of coping. Annals of Behavioral Medicine, 35(2).

Hawari, D. (2016). Manajemen Stress, Cemas dan Depresi. Jakarta: Balai Penerbit FKUI.

Izzati, W., \& Vahana, N. E. (2014). Hubungan Dukungan Keluarga Dengan Mekanisme Koping Pasien Hiv / Aids Di Poli Serunai Rs Achmad Mochtar Bukittinggi 2013. Afiyah, I(I), 1-8. Retrieved from http://ejournal.stikesyarsi.ac.id/index.php/JAV1N $1 /$ article/view/4

KEMENKES RI. (2020). Infodatin HIV AIDS. Kesehatan, $1-8 . \quad$ Retrieved from http://www.depkes.go.id/resources/download/pusd atin/infodatin/Infodatin AIDS.pdf

Kusmini, T. (2010). Mediasi Komunikasi Kelompok Dukungan Sebaya Semarang Plus Dalam pemulihan Hubungan Pasca Konflik Antara ODHA (Orang Dengan HIV/AIDS) dan Keluarga ODHA. Development, 62(November 1994), 1-2.

Notoadmojo, S. (2010). Metodologi Penelitian Kesehatan. Jakarta: Rhineka Cipta.
Nursalam. (2013). Asuhan Keperawatan pada Pasien Teerinfeksi HIV AIDS. Jakarta: Salemba Medika.

Pardita YPD, S. K. (2014). Analisis Dampak Sosial, Ekonomi,dan Psikologis Penderita HIV AIDS di Kota Denpasar. Jurnal Buletin Studi Ekonomi, 19(2).

Priharwanti, A., \& Raharjo, B. B. (2018). Problems Focused Coping Penderita HIV Positif. Public Health Perspective Journal, 2(2), 131-139.

Roy, S. C. (2009). The Roy Adaption Model (3 rd). Mosby , Elsevier.

Salami, S., Muvira, A. A., \& Yualita, P. (2021). Studi Kualitatif Strategi Koping Penderita HIV AIDS di Kota Bandung A Qualitative Study of Coping Strategies among People Living with HIV / AIDS in Bandung. 8(1), 22-30.

Sandu, S., Yuli, P., \& Eva, A. (2016). Teori Adaptasi Callista Roy ( Coping Mechanism on People Living with HIV Using Theory of Adaptation Callista Roy ). Jurnal Ners, 11(2), 256-260.

Shor, E., Roelfs, D. J., \& Yogev, T. (2013). The strength of family ties: A meta-analysis and metaregression of self-reported social support and mortality. Social Networks, 35(4), 626-638. https://doi.org/10.1016/j.socnet.2013.08.004

Smet, B. (2014). Psikologi Kesehatan. Jakarta: Gramedia Widiasaruna Indonesia.

Valeria, J., Surilena, S., Budiman, Y., Djauzi, S., \& Indah, H. (2016). Family support is not a risk factor of negative self-esteem in HIV/AIDS women. Universa Medicina, 34(1), 61. https://doi.org/10.18051/univmed.2015.v34.61-67

Wardoyo, E. H., Budyono, C., \& Asmara, I. G. Y. (2018). Peran Dukungan Keluarga Pasien HIV yang Menjalani Terapi Anti Retroviral di Klinik VCT RSUD Provinsi NTB terhadap Outcome Klinis. Jurnal Kedokteran Unram, 7(1), 5-10.

Wouters, E., Masquillier, C., \& le Roux Booysen, F. (2016). The Importance of the Family: A Longitudinal Study of the Predictors of Depression in HIV Patients in South Africa. AIDS and Behavior, 20(8), 1591-1602. https://doi.org/10.1007/s10461-016-1294-0 